\title{
Hygienic, sanitary, physical, and functional conditions of Brazilian public school food services ${ }^{1}$
}

\author{
Condições físico-funcionais e higiênico-sanitárias \\ das unidades de alimentação e nutrição de \\ escolas da Região Centro-Oeste, Brasil
}

Kênia Machado de ALMEIDA²

Maria Cláudia Porfirio ANDRÉ ${ }^{3}$

Maria Raquel Hidalgo CAMPOS ${ }^{4}$

Mário Ernesto Piscoya DÍAZ ${ }^{5}$

\section{A B S T R A C T}

\section{Objective}

To verify the physical, functional, hygienic, and sanitary conditions of the food services of municipal schools located in the Brazilian Midwest region.

\section{Methods}

This is a cross-sectional study of 296 school food services conducted from February to June 2012. The food services were assessed by a semi-structured check list divided into the following sections: physical conditions, available equipment, food handlers' conduct, and food service cleaning processes and procedures. The study variables were classified as compliant or noncompliant with the regulations passed by the National Sanitary Surveillance Agency.

\section{Results}

Noncompliances were found in all study food services, especially with respect to food service conditions, and the wiring and plumbing in the food preparation area. In this section, 62.7 to $95.9 \%$ of the food services did not comply with nine out of the thirteen study items. The main problems were: poorly cleaned external areas,

1 Article based on the master's thesis of KM ALMEIDA intitled "Condições físico-funcionais e higiênico-sanitárias das Unidades de Alimentação e Nutrição de escolas da Região Centro-Oeste, Brasil”. Universidade Federal de Goiás; 2013.

2 Universidade Federal de Goiás, Faculdade de Nutrição, Programa de Pós-Graduação em Nutrição e Saúde. R. 227, Qd. 68, s/n.,

Setor Leste Universitário, 74605-080, Goiânia, GO, Brasil. E-mail: <kenianutricionista@gmail.com>.

3 Universidade Federal de Goiás, Instituto de Patologia Tropical e Saúde Pública, Departamento de Microbiologia, Imunologia,

Parasitologia e Patologia. Goiânia, GO, Brasil.

${ }^{4}$ Universidade Federal de Goiás, Faculdade de Nutrição, Curso de Nutrição. Goiânia, GO, Brasil.

5 Universidade Federal de Goiás, Instituto de Matemática e Estatística, Curso de Estatística. Goiânia, GO, Brasil. 
deteriorated walls, floors, ceilings, roofs, drains, and roof gutters; and unscreened doors and windows, allowing the entrance of insects; among others. The main noncompliance regarding processes and procedures was the uncontrolled temperature of the ready-to-eat foods.

\section{Conclusion}

The conditions of the study food services are unsatisfactory for the production of safe meals, possibly compromising meal quality, food safety, and the effectiveness of the School Food Program.

Indexing terms: Food security. Good manipulation practices. School food.

\section{R E S U M O}

\section{Objetivo}

Verificar as condições físico-funcionais e higiênico-sanitárias das Unidades de Alimentação de Nutrição de escolas públicas municipais localizadas na Região Centro-Oeste do País.

\section{Métodos}

Estudo transversal, realizado entre fevereiro e junho de 2012, em 296 unidades de alimentação e nutrição escolares. Aplicou-se nestas unidades checklist semi-estruturado, dividido em blocos referentes às condições estruturais, disponibilidade de equipamentos, atuação dos manipuladores de alimentos, processos e procedimentos e higienização ambiental. Considerando as determinações da Agência Nacional de Vigilância Sanitária para Unidades de Alimentação e Nutrição, classificou-se as variáveis analisadas em conforme ou não conforme.

\section{Resultados}

Em todas as unidades de alimentação e nutrição que participaram do estudo identificou-se inadequações, com destaque para às condições dos edifícios e instalações da área de preparo dos alimentos. Neste bloco, 62,7 a 95, 9\% das unidades apresentaram não conformidade para nove dos treze itens avaliados, os principais problemas foram: higienização precária da área externa; paredes, pisos, forros, tetos, ralos e canaletas inadequados; portas e janelas sem telas de proteção contra a entrada de insetos, dentre outros. Quanto aos processos e procedimentos, a principal inadequação foi a falta de controle de temperatura dos alimentos prontos para o consumo.

\section{Conclusão}

As unidades de alimentação e nutrição pesquisadas apresentam-se em condições insatisfatórias para a produção de uma alimentação escolar segura do ponto de vista higiênico-sanitário, o que pode comprometer a qualidade da refeição, a Segurança Alimentar e Nutricional no ambiente escolar e a efetivação do Programa Nacional de Alimentação Escolar.

Termos de indexação: Segurança alimentar e nutricional. Boas práticas de manipulação. Alimentação escolar.

\section{NTRODUCTION}

A food service is "an organized service performing a sequence of actions that aim to supply balanced meals within established dietary and hygienic standards and meet the nutritional needs of its clientele, according to the financial means of the institution" (p.35)1. In schools, these food services are the kitchens where school food is prepared.

The supply of microbiologically safe foods in schools is regulated by Law $n^{\circ} 11.947 / 2009^{2}$ because their clientele consists of children, the most vulnerable group to foodborne diseases ${ }^{3-5}$. These disease are caused by foods contaminated with pathogenic microorganisms or chemical products ${ }^{6}$.

The use of good practices, including appropriate and safe procedures, from facility construction to meal distribution, allows food services to ensure safe preparations ${ }^{7}$.

The characteristics of the physical structure of a food service, such as flooring, wall and ceiling coating, door and window conditions, drain size 
and location, lighting, ventilation, temperature, and moisture, among others, directly affect its cleanliness $^{8}$. Identifying the risk of food contamination allows determining what needs improvement and the stage of food preparation that is compromising food safety 9 .

Today the Technical Regulations for Good Food Service Practices is provided by Resolução da Diretoria Colegiada (RDC, Board Resolution) $n^{\circ} 216$, passed on September 15, 2004 by the Agência Nacional de Vigilância Sanitária (Anvisa, National Sanitary Surveillance Agency). The objective of this RDC is to improve sanitary control and better protect people's health ${ }^{7}$. However, numerous school food services do not comply with these regulations and risk cross-contamination ${ }^{3,49-12}$. In Salvador (BA), the conditions of approximately $57 \%$ of the 235 schools assessed were unsatisfactory ${ }^{3}$.

Given this perspective and that sanitation is directly associated with the assurance of safe foods $^{13}$, school meals must be produced in food services with good infrastructure and handling practices.

The Programa Nascional de Alimentação Escolar (PNAE, National School Food Program) is one of the social policies and programs that aim to promote food and nutrition security. Created in the 1950s, this nationwide, governmentsponsored school food program became structured for the first time. Until then the program was known as school "lunch"14. The guidelines of the program include the use of healthy foods that promote schoolchildren's growth and development according to their age group, health status, and occasionally, special needs $^{14,15}$.

The municipal and state PNAE managers must ensure the acquisition, transportation, storage, and preparation of meals that remain safe until consumption ${ }^{15}$.

Given the above, RDC n'216/20047, and Law $n^{\circ} 11.947 / 2009^{2}$, the present study aimed to check the physical, functional, hygienic, and sanitary conditions of the food services of municipal schools located in the Midwest region of the country.

\section{METHODS}

This is a cross-sectional, descriptive study with a quantitative approach ${ }^{16}$ approved by the Research Ethics Committee of the Universidade Federal de Goiás (UFG) on October 21, 2011, under Protocol number 354/11. All participants signed an Informed Consent Form before study enrollment.

Data were collected by six dieticians who received 20-hour training to standardize personal conduct and checklist scoring. These dieticians visited the food services of municipal schools in the Brazilian Midwest states, namely Goiás, Mato Grosso do Sul, and Mato Grosso, from February to June 2012.

The schools were sampled in two stages. The first stage consisted of selecting municipalities in the Midwest that did not comply with Article 14 of Law $n^{\circ} 11.947$ passed on June 6, 2009². This article establishes that at least $30 \%$ of the funds transferred to PNAE by the Fundo Nacional de Desenvolvimento da Educação (FNDE, National Education Development Fund) be used for purchasing foods from family farms ${ }^{2}$. There was a survey of municipalities that received training or consulting services from the Centro Colaborador em Alimentação e Nutrição (Cecane) of the UFG of the Midwest Region in the last years, also excluded these municipalities, because these activities have a positive impact on the physical, functional, hygienic, and sanitary conditions of school food services ${ }^{17}$.

A total of 168 municipalities with 938 municipal elementary and high schools were selected. Based on the number of schools in these municipalities, a prevalence of food services with unsatisfactory sanitary conditions of approximately $50 \%$, and a $95 \%$ Confidence Interval $(95 \% \mathrm{Cl})$, the final sample should contain at least 273 municipal schools. An additional 10\% was added 
to the minimum sample size to compensate for losses, so the final sample consisted of 300 schools, as recommended by Hoffmann ${ }^{18}$.

Sixty municipalities were randomly selected from the 168 that met the inclusion criteria, on the additional condition that they had a dietician in charge of the PNAE, as determined by Law $n^{\circ} 11,947 / 2009^{2}$.

In the second stage, the schools were selected. The number of schools selected per municipality was given by the proportional distribution of the total number of schools. Only municipal elementary and high schools were included. State, indigenous, and Quilombola schools, preschools, and daycare centers were excluded. State schools were excluded because they are managed and followed by their State Department of Education; indigenous and Quilombola schools were excluded because they have particularities related to these communities; and preschools and daycare centers were excluded because they require special food services, capable of catering for sucklings.

As determined by RDC $n^{\circ} 216 / 2004^{7}$, a semi-structured checklist was created for data collection. The checklist was divided into the following sections: a) Physical, plumbing, and wiring conditions in the food preparation area; b) Equipment, utensils, and handlers; c) Handlers; d) Processes and procedures; and e) Food service cleaning.

Food handlers were asked to answer a specific questionnaire called "Handlers," which consisted of the following variables: type of job, type of employment contract, weekly hours of work, participation in training courses and subjects covered by said courses, having jobs other than food handling, and health checkup frequency. The instruments created and validated by Cecane of the Universidade Federal de São Paulo (Unifesp) ${ }^{19}$ helped to assess the physical, functional, hygienic, and sanitary conditions and the food handling practices of the study food services.
As the data were tabulated, the following categories were attributed to each study item: noncompliant (0); compliant (1); and not applicable (2); as recommended by RCD $n^{\circ} 216 / 20047$. A period (.) was attributed to unanswered questions, considered losses.

The database was created in the spreadsheet Microsoft Excel version 2007. The data were entered twice to check for inconsistencies, which was done by the statistical package Stata/SE version 11.0.

The percentages of adequacy were estimated for the entire sample and by state (Goiás, Mato Grosso, and Mato Grosso do Sul) and segment (urban and rural). Measures of association based on the Chi-square statistic assessed the relationship between compliance and noncompliance. A type I error of 0.05 was considered for the statistically significant results. The compliance rates of the study variables were calculated to diagnose the conditions of the school food services and to identify the points with the greatest noncompliance rates.

\section{RES U LTS}

Of the 59 municipalities in the Midwest region that participated in the study, $22.0 \%$ $(n=13)$ were in Goiás, $30.5 \%(n=18)$ were in Mato Grosso do Sul, and $47.5 \%(n=28)$ were in Mato Grosso. The single loss was due to political problems in one of the selected municipalities. Hence, the sample consisted of 296 municipal school food services, of which $76.0 \% \quad(n=225)$ were in urban areas and $24.0 \%(n=71)$ were in rural areas.

None of the study food services were compliant with all Good Handling Practices (GHP). In 294 (99.3\%) schools, the meals were prepared in-house; in two rural schools, the meals were prepared at the cooks' homes.

Many items regarding the physical, plumbing, and wiring conditions of the food preparation area (Section A) were noncompliant 
with RDC n²16/2004. Items with noncompliance rates in excess of $86 \%$ were (Table 1): problems in the external areas of the food services, such as unused objects, insects and other animals, and/ or exposed garbage; hard-to-clean floors; walls with mildew, moisture, peeling paint, and cracks; ceilings and roofs that leak or allow the entrance of insects; drains and gutters unprotected against the entrance of rodents and/or insects in the 67 food services with drains and gutters inside the food service; unscreened doors and windows; storage areas with poor lighting and ventilation, and unused objects;

Items with noncompliance rates below $40.0 \%$ were (Table 1): use of water from wells, cisterns, springs, rivers, streams, and water trucks, among others, none of which were guaranteed to be treated or potable; inappropriate food storage, such as foods inside cardboard boxes, on tables, chairs, floor and/or in unventilated cabinets. The storages in 268 (90.6\%) schools were near the food preparation area; in 28 (9.5\%) schools the foods were stored far from the food preparation area, such as in classrooms or even outside the school; inappropriate storage of foods that required refrigeration but were not refrigerated. Foods were stored close to cleaning materials in 57 (19.6\%) food services, and close to school materials (books, paper, furniture, etc.) in $18(6.1 \%)$ food services; water tank not cleaned often enough: in 50 (19.3\%) food services, the water tanks had not been cleaned in over six months, and in 36 (13.9\%) food services, they had never been cleaned. Only 84 (37.7\%) food services kept a water tank cleaning record and 10 (3.4\%) food services did not have a water tank; of these, six $(60.0 \%)$ were in urban areas and four $(40.0 \%)$ were in rural areas.

Noncompliant items in the food distribution and consumption areas were found in $73.4 \%$ of the food services because they did not have cafeterias. In these schools the meals were served in the courtyard or classrooms (Table 1).

With respect to equipment (Section B), all food services had a stove; 294 (99.3\%) food services had commercial stoves; one food service located in a rural area had a wood-burning stove and a residential stove (Table 2 ).

Six $(2.0 \%)$ food services located in rural areas had no refrigerators. Nine $(3.0 \%)$ food services had only a freezer, and of these, six $(66.7 \%)$ were in urban areas and the remainder, in rural areas.

Only 53 (17.9\%) food services had conventional weighing scales; six $(2.0 \%)$ had platform scales; one $(0.3 \%)$ had the two types of scales; and $238(80.4 \%)$ had no scale. Only two

Table 1. Compliance of municipal schools in the Brazilian Midwest region with RDC $n^{\circ}$ 216/2004 regarding physical, plumbing, and wiring variables in the food preparation areas (Section A). Brazil, 2012.

\begin{tabular}{|c|c|c|c|c|c|c|}
\hline \multirow{2}{*}{ Variables } & \multicolumn{2}{|c|}{ Compliant } & \multicolumn{2}{|c|}{ Non-compliant } & \multicolumn{2}{|c|}{ Total } \\
\hline & $\mathrm{n}$ & $\%$ & $n$ & $\%$ & $\mathrm{n}$ & $\%$ \\
\hline Food service water source & 180 & 60.8 & 116 & 39.2 & 296 & 100.0 \\
\hline External area cleanliness & 20 & 6.8 & 275 & 93.2 & 295 & 100.0 \\
\hline Food service flooring & 20 & 6.8 & 276 & 93.2 & 296 & 100.0 \\
\hline Food service walls & 18 & 6.1 & 278 & 93.9 & 296 & 100.0 \\
\hline Food service ceiling and roof & 12 & 4.1 & 283 & 95.9 & 295 & 100.0 \\
\hline Food service drains and gutters & 9 & 13.4 & 58 & 86.6 & 67 & 100.0 \\
\hline Door and window screens & 16 & 5.4 & 278 & 94.6 & 294 & 100.0 \\
\hline Proper storage lighting, ventilation, and/or absence of unused objects & 8 & 2.7 & 285 & 97.3 & 293 & 100.0 \\
\hline Raw materials stored on shelves, racks, or pallets. & 176 & 61.1 & 112 & 38.9 & 288 & 100.0 \\
\hline Storage conditions of items that require refrigeration & 239 & 84.7 & 43 & 15.3 & 282 & 100.0 \\
\hline Proper food distribution and consumption areas & 78 & 26.6 & 215 & 73.4 & 293 & 100.0 \\
\hline Water tank cleaning frequency & 173 & 66.8 & 86 & 33.2 & 259 & 100.0 \\
\hline Record of water tank cleanings & 84 & 37.7 & 139 & 62.7 & 223 & 100.0 \\
\hline
\end{tabular}


Table 2. Availability of equipment and utensils (Section B) in the food services of municipal schools of the Brazilian Midwest region. Brazil. 2012.

\begin{tabular}{lcc}
\hline \multirow{2}{*}{ Equipment/Utensils } & \multicolumn{2}{c}{ Number of school food services with the equipment/utensil } \\
\cline { 2 - 3 } & $\mathrm{n}$ & $\%$ \\
\hline Commercial stove & 294 & 99.3 \\
Residential stove & 19 & 6.4 \\
Wood-burning stove & 1 & 0.3 \\
Single-door residential refrigerator & 172 & 58.1 \\
Double-door residential refrigerator & 112 & 37.8 \\
Freezer & 275 & 92.9 \\
Walk-in cooler & 9 & 3.0 \\
Conventional weighing scale & 53 & 17.9 \\
Platform weighing scale & 6 & 2.0 \\
Thermometer & 2 & 0.7 \\
\hline
\end{tabular}

Table 3. Compliance of municipal schools in the Brazilian Midwest region with RDC $n^{\circ} 216 / 2004$ regarding processes and procedures performed in the food preparation areas (Section D). Brazil, 2012.

\begin{tabular}{|c|c|c|c|c|c|c|}
\hline \multirow{2}{*}{ Variables } & \multicolumn{2}{|c|}{ Compliant } & \multicolumn{2}{|c|}{ Non-compliant } & \multicolumn{2}{|c|}{ Total } \\
\hline & $n$ & $\%$ & $\mathrm{n}$ & $\%$ & $\mathrm{n}$ & $\%$ \\
\hline Goods receiving clerk checks the raw materials upon receipt & 58 & 20.4 & 227 & 79.6 & 285 & 100.0 \\
\hline Hand washing frequency & 233 & 80.9 & 55 & 19.1 & 288 & 100.0 \\
\hline Hand sanitization & 54 & 19.0 & 230 & 81.0 & 284 & 100.0 \\
\hline Utensils used on raw foods are sanitized before being used on cooked foods & 17 & 6.0 & 268 & 94.0 & 285 & 100.0 \\
\hline Sanitization of fruits and vegetables & 102 & 37.2 & 172 & 62.8 & 274 & 100.0 \\
\hline Food thawing process & 207 & 72.1 & 80 & 27.9 & 287 & 100.0 \\
\hline Ready-to-eat foods are protected & 140 & 50.7 & 136 & 42.3 & 276 & 100.0 \\
\hline Control of ready-to-eat food temperature & 1 & 0.3 & 288 & 99.7 & 289 & 100.0 \\
\hline Leftover storage & 23 & 85.2 & 4 & 14.8 & 27 & 100.0 \\
\hline
\end{tabular}

(0.7\%) food services had thermometers (Table 2 ). Equipment maintenance was done regularly in $175(60.1 \%)$ food services.

Meals were prepared by cooks in 275 (92.9\%) food services, and by handymen, teachers, and even students' parents in the remainder food services (Section C).

In 52 (18.1\%) food services, the food handlers were properly dressed with uniforms in good conditions (clean and without holes or tears) and wearing closed shoes. In 264 (91.7\%) food services, the handlers were wearing disposable caps, hair nets, or headscarves. The use of accessories and/or nail polisher was seen in 135 (47.0\%) food services.

Many processes and procedures were noncompliant (Section D), reflecting the lack of
GHP in the meal preparation area, from goods receiving to meal distribution.

The main noncompliances (Table 3) were: the temperature of the ready-to-eat foods was not controlled. Only one food service had a food warmer to keep the food above $60^{\circ} \mathrm{C}$. However, 289 (99.7\%) food services served the meals as soon as they were ready; utensils used on raw foods were not sanitized before they were reused on cooked foods; hands were not sanitized properly because only water and soap or water alone was used for hand washing; upon receipt, goods' temperature, expiration date, and package integrity were not checked; in $37.2 \%$ of the food services, the fruits and vegetables were not sanitized properly because only water or water and soap and/or vinegar were used. 
The highest compliance rates were found for the following items (Table 3 ): storage of leftovers under refrigeration: $85.2 \%$ of the 27 food services that saved the leftovers stored them properly; proper hand washing frequency, since the handlers reported washing their hands before they started their work, every time they changed activities, after going to the restroom, after touching the garbage can, and whenever necessary. However, two $(0.7 \%)$ food services did not have running water; foods thawed under refrigeration, by a microwave oven, or cooked without prior thawing; the manner in which ready-to-eat foods were protected: with a plastic or paper food wrap, or a closed container. Noncompliant food services either did not protect the foods or covered them with a dish towel.

In 289 (99.7\%) food services, the meats were always well done; all units (100.0\%) served their eggs hard cooked. Forty-seven (16.4\%) food services served pies, potato salad with mayonnaise, and creams, items whose ingredients include raw eggs.

Food service cleaning (Section E) included washing the floor daily (93.5\%, $n=272)$, weekly, or monthly; 149 (59.1\%) food services used chlorine-based bleach, 96 (33.0\%) food services used only water and soap, and 21 (7.2\%) food services used only water or water and some other non-sanitizing product.

In 252 (86.6\%) food services, the tables were washed daily; 28 (9.6\%) food services washed them weekly; and five (1.7\%) food services had never washed them. Of the food services that cleaned the tables, 149 (52.6\%) used water, soap, and a sanitizing substance (chlorine-based bleach, $70 \%$ alcohol, or quaternary ammonium compounds).

Eighty-five (29.0\%) food services had step garbage cans with garbage bags; 208 (71.0\%) food services did not dispose of their garbage properly (inappropriate container or location). One hundred $(35.0 \%)$ food services cleaned their garbage cans, 165 (57.7\%) food services washed their garbage cans with water and soap, and 21
(7.3\%) food services did not wash their garbage cans or used only water to wash them.

Most ( $n=188,68.6 \%)$ food services relied on professional chemical pest control. Forty-five (16.4\%) food services had some employee or another untrained individual do the job, and 41 $(15.0 \%)$ food services did not control pests; 173 (67.8\%) food services performed chemical pest control every semester or more often; 48 (18.8\%) performed chemical pest control annually; and $51(22.8 \%)$ food services did not perform chemical pest control regularly or at all.

When the food services located in urban and rural areas were compared, those in urban areas presented higher compliance rates for the following items: water source, storage conditions of foods that require refrigeration, meal distribution and consumption area, water tank cleaning frequency, record of water tank cleanings, dedicated cook, use of headgear, use of uniforms, hand sanitization, preparations containing eggs, food thawing, table sanitization, garbage cans, and professional pest control (Table 4).

Food services located in rural areas presented higher compliance rates only for their storage conditions: they had proper lighting, ventilation, and absence of unused objects $(p<0.05)$ (Table 4).

All food handlers from all study food services who were present on data collection day were interviewed, totaling 482 food handlers or 1.6 food handlers per food service.

The jobs of 425 (89.8\%) food handlers were compatible with food handling, that is, they were either the cook or the cook's assistant, but $48(10.2 \%)$ jobs did not include food handling; these individuals were either handymen or administrative workers. Most (69.7\%, $\mathrm{n}=331$ ) food handlers had passed an admission test for the job; 120 (25.3\%) were hired without a test, and 24 (5.0\%) were outsourced. Roughly half $(51.6 \%, n=245)$ of the food handlers worked from 30 to 40 hours a week, 213 (44.8\%) worked 
Table 4. Comparative distribution of the food services of municipal schools located in the Brazilian Midwest region regarding compliance with RDC n²16/2004. Brazil, 2012.

\begin{tabular}{|c|c|c|c|c|c|}
\hline \multirow{3}{*}{ Variables } & \multicolumn{4}{|c|}{$\begin{array}{c}\text { Number of schools compliant } \\
\text { with RDC } n^{\circ} 216 / 2004\end{array}$} & \multirow{3}{*}{$p$-value* } \\
\hline & \multicolumn{2}{|c|}{ Urban } & \multicolumn{2}{|c|}{ Rural } & \\
\hline & $\mathrm{n}$ & $\%$ & $\mathrm{n}$ & $\%$ & \\
\hline \multicolumn{6}{|l|}{ Section A: Physical, plumbing, and wiring conditions of the food preparation areas } \\
\hline Food service water source & 178 & 79.1 & 2 & 2.8 & $0.00^{* *}$ \\
\hline External area cleanliness & 16 & 7.1 & 4 & 5.6 & 0.66 \\
\hline Food service flooring & 17 & 7.6 & 4 & 5.6 & 0.58 \\
\hline Food service walls & 13 & 5.8 & 5 & 7.0 & 0.70 \\
\hline Food service ceiling and roof & 7 & 3.1 & 5 & 7.0 & 0.14 \\
\hline Screened doors and windows & 13 & 5.8 & 3 & 4.2 & 0.74 \\
\hline Proper storage lighting, ventilation, and/or absence of unused objects & 3 & 1.8 & 5 & 7.2 & $0.01^{* *}$ \\
\hline Raw materials stored on shelves, racks, or pallets & 139 & 62.6 & 38 & 57.6 & 0.46 \\
\hline Storage conditions of items that require refrigeration & 189 & 85.5 & 49 & 80.3 & $0.00^{* *}$ \\
\hline Cleaning materials stored away from foods & 181 & 82.3 & 52 & 74.3 & 0.14 \\
\hline School materials stored away from foods & 210 & 94.6 & 67 & 95.7 & 0.87 \\
\hline Proper meal distribution and consumption areas & 67 & 30.0 & 11 & 16.9 & $0.02^{* *}$ \\
\hline Water tank cleaning frequency & 146 & 71.9 & 26 & 44.1 & $0.00^{* *}$ \\
\hline Record of the water tank cleanings & 73 & 39.7 & 11 & 25.0 & $0.00^{* *}$ \\
\hline \multicolumn{6}{|l|}{ Section C: Food handlers } \\
\hline Dedicated cook & 215 & 95.6 & 60 & 84.5 & $0.00^{* *}$ \\
\hline Use of headgear & 217 & 98.6 & 51 & 83.6 & $0.00^{* *}$ \\
\hline Use of proper uniforms & 49 & 21.9 & 4 & 6.3 & $0.00^{* *}$ \\
\hline Use of accessories & 119 & 53.1 & 34 & 54.8 & 0.16 \\
\hline \multicolumn{6}{|l|}{ Section D: Processes and procedures } \\
\hline Hand washing frequency & 172 & 77.1 & 57 & 87.7 & 0.06 \\
\hline Hand sanitization & 36 & 16.4 & 10 & 15.9 & $0.03^{* *}$ \\
\hline Raw materials checked upon receipt & 47 & 21.2 & 12 & 19.0 & 0.71 \\
\hline Ready-to-eat foods are protected & 102 & 47.4 & 35 & 57.4 & 0.17 \\
\hline Utensils used on raw foods are sanitized before being used on cooked foods & 15 & 6.8 & 2 & 3.2 & 0.26 \\
\hline Ready-to-eat food holding time & 224 & 100.0 & 65 & 100.0 & 0.59 \\
\hline Storage of ready-to-eat foods & 1 & 0.4 & 0 & 0.0 & 0.59 \\
\hline Preparations with eggs & 194 & 87.4 & 47 & 72.3 & $0.00^{* *}$ \\
\hline Proper food thawing & 156 & 70.6 & 37 & 56.9 & 0.06 \\
\hline \multicolumn{6}{|l|}{ Section E: Food service cleaning } \\
\hline Table sanitization & 121 & 55.0 & 27 & 42.8 & 0.07 \\
\hline Floor sanitization & 129 & 57.3 & 43 & 65.2 & 0.26 \\
\hline Garbage can & 76 & 33.8 & 12 & 17.6 & $0.01^{* *}$ \\
\hline Garbage can sanitization & 77 & 34.8 & 23 & 35.4 & 0.86 \\
\hline Professional chemical pest control & 165 & 78.6 & 23 & 36.5 & $0.00^{* *}$ \\
\hline
\end{tabular}

Note: * $p$-value associated with Chi-square tests of independence (Pearson's Chi-square, Fisher's exact test, or likelihood ratio as needed); ${ }^{* *} p$-value $<0.05$.

from 20 to 30 hours a week, and the remainder (3.6\%) worked fewer than 20 hours a week.

Most $(78.5 \%, n=373)$ food handlers were dedicated exclusively to meal preparation, and $102(21.5 \%)$ were teachers, handymen, or administrative workers. Some $(26.9 \%, n=128)$ food handlers underwent health checkups every semester, 179 (37.7\%) had not undergone a health checkup in the last year or more, and the remainder (35.4\%) never underwent any health checkup to handle food.

Regarding training, 115 (24.2\%) food handlers had never attended a training course, $112(23.6 \%)$ food handlers had not attended a 
training course for at least one year, 188 (39.7\%) food handlers had attended a training course in the last semester, and 59 (12.4\%) food handlers had attended a training course in the last year. The most common subject in training courses was food hygiene, reported by 321 (89.4\%) food handlers.

When the compliance rates for the physical, plumbing, and wiring conditions of the food preparation areas, food handlers' conduct,

Table 5. Percentage of compliance with RDC $n^{\circ} 216 / 2004$ of the study items of food services of municipal schools in the Brazilian Midwest region. Brazil, 2012.

\begin{tabular}{|c|c|c|c|c|c|c|c|}
\hline \multirow{2}{*}{ Variables } & \multicolumn{2}{|c|}{ GO } & \multicolumn{2}{|c|}{ MS } & \multicolumn{2}{|c|}{ MT } & \multirow{2}{*}{$p$-value } \\
\hline & $\mathrm{n}$ & $\%$ & $\mathrm{n}$ & $\%$ & $\mathrm{n}$ & $\%$ & \\
\hline \multicolumn{8}{|l|}{$\begin{array}{l}\text { Section A: Physical, plumbing, and wiring conditions of the food } \\
\text { preparation areas }\end{array}$} \\
\hline Food service water source & 35 & 67.3 & 57 & 81.4 & 88 & 50.6 & $0.00^{\star *}$ \\
\hline External area cleanliness & 2 & 3.8 & 6 & 8.6 & 12 & 6.9 & 0.59 \\
\hline Food service flooring condition & 3 & 5.8 & 10 & 14.3 & 8 & 4.6 & $0.03^{* *}$ \\
\hline Food service wall condition & 7 & 13.5 & 4 & 5.7 & 7 & 4.0 & $0.04^{* *}$ \\
\hline Food service ceiling and roof condition & 6 & 11.5 & 3 & 4.3 & 3 & 1.7 & $0.01^{* *}$ \\
\hline Screened doors and windows & 3 & 5.8 & 6 & 8.6 & 7 & 4.1 & 0.61 \\
\hline Proper storage lighting, ventilation, and/or absence of unused objects & 1 & 1.9 & 1 & 1.4 & 6 & 3.5 & 0.63 \\
\hline Raw materials stored on shelves, racks, or pallets & 40 & 80.0 & 39 & 58.2 & 98 & 57.3 & $0.01^{* *}$ \\
\hline Storage of items that require refrigeration & 49 & 94.2 & 59 & 85.5 & 130 & 80.7 & $0.01^{* *}$ \\
\hline Cleaning materials stored away from foods & 47 & 94.0 & 48 & 70.6 & 138 & 80.2 & $0.01^{* *}$ \\
\hline School materials stored away from foods & 49 & 100.0 & 66 & 94.3 & 162 & 93.6 & $0.00^{* *}$ \\
\hline Proper meal distribution and consumption areas & 4 & 7.8 & 15 & 21.7 & 59 & 34.1 & $0.00^{* *}$ \\
\hline Water tank cleaning frequency & 21 & 47.7 & 55 & 85.9 & 96 & 62.3 & $0.00^{* *}$ \\
\hline Record of water tank cleanings & 19 & 51.4 & 24 & 41.4 & 41 & 30.8 & $0.04^{* *}$ \\
\hline \multicolumn{8}{|l|}{ Section C: Food handlers } \\
\hline Dedicated cook & 52 & 96.2 & 70 & 97.1 & 174 & 90.2 & 0.10 \\
\hline Use of headgear & 47 & 97.9 & 70 & 100.0 & 164 & 92.7 & $0.02^{* *}$ \\
\hline Use of proper uniforms & 46 & 34.8 & 70 & 42.9 & 171 & 4.1 & $0.00^{* *}$ \\
\hline Use of accessories & 45 & 68.9 & 70 & 62.9 & 171 & 45.6 & $0.00^{* *}$ \\
\hline \multicolumn{8}{|l|}{ Section D: Processes and procedures } \\
\hline Hand washing frequency & 48 & 91.7 & 70 & 64.3 & 170 & 82.4 & $0.00^{* *}$ \\
\hline Hand sanitization & 48 & 25.0 & 70 & 22.9 & 166 & 10.8 & $0.04^{* *}$ \\
\hline Raw materials checked upon receipt & 46 & 15.2 & 70 & 30.0 & 169 & 18.3 & 0.08 \\
\hline Ready-to-eat foods are protected & 44 & 63.6 & 69 & 30.4 & 163 & 54.0 & $0.00^{* *}$ \\
\hline $\begin{array}{l}\text { Utensils used on raw foods are sanitized before being used on } \\
\text { cooked foods }\end{array}$ & 47 & 4.3 & 69 & 18.8 & 169 & 1.2 & $0.00^{* *}$ \\
\hline Ready-to-eat food holding time & 49 & 100.0 & 70 & 100.0 & 171 & 99.4 & 0.70 \\
\hline Storage of ready-to-eat foods & 48 & 0.0 & 70 & 1.4 & 171 & 0.0 & 0.21 \\
\hline Sanitization of fruits and vegetables & 49 & 28.6 & 68 & 45.6 & 168 & 30.3 & $0.01^{* *}$ \\
\hline Preparations with eggs & 48 & 64.6 & 68 & 92.6 & 171 & 86.0 & $0.00^{* *}$ \\
\hline Proper food thawing & 48 & 93.8 & 68 & 70.6 & 170 & 58.8 & $0.00^{* *}$ \\
\hline \multicolumn{8}{|l|}{ Section E: Food service cleaning } \\
\hline Table sanitization & 48 & 81.2 & 70 & 94.3 & 168 & 87.5 & 0.17 \\
\hline Floor sanitization & 49 & 46.9 & 70 & 64.3 & 172 & 60.5 & 0.14 \\
\hline Garbage can & 49 & 32.7 & 70 & 40.0 & 174 & 25.3 & 0.07 \\
\hline Garbage can sanitization & 48 & 45.8 & 70 & 40.0 & 168 & 29.8 & 0.20 \\
\hline Professional chemical pest control & 44 & 52.3 & 63 & 82.5 & 166 & 68.1 & $0.02^{* *}$ \\
\hline
\end{tabular}

Note: * $p$-value associated with Chi-square tests of independence (Pearson's Chi-square, Fisher's exact test, or likelihood ratio as needed); ${ }^{* *} p$-value $<0.05$.

GO: Goiás; MS: Mato Grosso do Sul; MT: Mato Grosso. 
rightness of the processes and procedures, and food service cleaning were compared by state, Goiás presented the highest compliance rates and Mato Grosso the lowest (Table 5).

\section{DISCUSSION}

School food quality includes not only nutritional aspects but also safety aspects. Compliance with sanitary requirements protects and promotes the health of public school students $^{4}$ and avoids foodborne disease outbreaks.

In the United States, foodborne diseases affect approximately one in every six people; yearly, 128,000 people are hospitalized and 3,000 $\mathrm{die}^{20}$. Of the cases reported in Brazil from 2000 to $2011,9.09 \%$ occurred in educational institutions ${ }^{21}$.

The lack of strict control during food preparation, poor physical conditions of the food preparation areas, and bad practices during food preparation processes and procedures may contaminate foods and compromise their safety, increasing the risks of foodborne diseases and their consequences ${ }^{22}$.

Foodborne disease outbreaks and food service studies indicate that many areas where school meals are prepared and distributed are not appropriate for meal production ${ }^{9,10,12}$.

High noncompliance rates may stem from the lack of specific regulations for school food services, which are much more similar to residential kitchens than commercial kitchens. School and institutional food services are subject to the same legislation, which may impair the implementation of more complex regulations ${ }^{9}$. However, this does not justify noncompliance with the basic requirements for the production of safe meals, such as personal and food service hygiene.

Regarding physical, plumbing, and wiring conditions (Section A), a study pointed out that even food services of daycares located in the municipality of São Paulo (SP) had physical noncompliances, especially doors without door sweeps and unscreened windows ${ }^{9}$. These noncompliances were also found in $94.6 \%$ of the study food services, and were the second most common noncompliances.

In Salvador (BA), of the 253 municipal and state school food services covered by PNAE, only $0.4 \%$ were in good conditions; $57.0 \%$ were unsatisfactory, especially regarding their physical, plumbing, and wiring conditions, which compromises the preparation of safe school meals ${ }^{4}$.

In the same city, some of the main problems were inappropriate cleaning of the food preparation areas and surfaces, unscreened doors and windows, unprotected lamps, inappropriate garbage can sites, and absence of liquid soap and paper towels in restrooms and kitchens ${ }^{11}$.

Contrary to the study data, $37.5 \%$ of the 24 food services of state schools in the city of São Paulo (SP) presented good hygienic and sanitary conditions; the most common problem was inappropriate cleaning of stoves and refrigerators $^{12}$.

In agreement with the present study, $100 \%$ of the school food services assessed in Natal (RN) presented noncompliances. The lack of cafeterias and meal distribution outside the kitchen, that is, in classrooms, halls, and sport courts $^{10}$ were among the greatest problems in both studies. The lack of cafeterias is also common in the schools of Ghana and South Africa, but these countries do not yet have effective school food programs like Brazil ${ }^{23}$.

According to RDC n²16/20047, water tanks should be cleaned at least once per semester, and the cleanings should be recorded. In the present study, $66.8 \%$ of the food services cleaned the water tanks at least once per semester, but most kept no records. Water is one of the most important recourses for meal production and a determinant of food safety. Improper water tank cleaning method and/or frequency can affect food safety and quality ${ }^{24}$. 
Regarding equipment and utensils (Section B), good use of the food service layout and enough devices to meet meal production requirements reduce workload and improve efficiency ${ }^{8}$. However, the present study found that essential items, such as refrigerator, weighing scale, and thermometer, were not available in all food services.

Thawing should be done under refrigeration with a temperature below $5{ }^{\circ} \mathrm{C}$ or in a convection oven ${ }^{7}$. Thawing in a microwave, water, or at room temperature requires controlling thawing time and temperature of the surface layer of the food ${ }^{25}$. Although nine food services did not have a refrigerator, only ten food services had a microwave oven, and nearly all food services did not have a thermometer, $72.1 \%$ of the food services thawed foods correctly: in the absence of the necessary equipment, they cooked the food in a pan or oven without prior thawing.

When foods are ready, they must be kept in clean food warmers in perfect working condition ${ }^{7}$; only one food service had a food warmer. However, $99.7 \%$ of the study food services served the meals as soon as they were ready, minimizing the risk of contamination.

Given the numerous physical noncompliances and absence of essential equipment in the study food services, public managers need to invest more in this sector, and dieticians, together with the School Food Council (CAE) need to participate more, to improve surveillance and guarantee safer meals.

In Salvador (BA), $49.4 \%$ of the food handlers had long nails, $70.6 \%$ used nail polishers, and in $51.7 \%$ of the food services, food handlers did not wash their hands often enough ${ }^{3}$. In Andalusia, Spain, the food handlers in $35.0 \%$ of the school canteens did not wash their hands properly, and in some canteens food handlers did not wash their hands at all ${ }^{25}$. The findings for the study food services were similar, except for hand washing frequency because $80.9 \%$ of the interviewed food handlers complied with the legislation.
Food handlers are one of the main sources of contamination by staphylococci and coliforms because these microorganisms inhabit human skin $^{24}$. However, although hand washing is critical for the production of safe meals, a study of 38 elementary schools in Hulu Langat (Malaysia) found that only $15.3 \%$ of the food handlers knew all the steps for proper hand washing and that this activity was neglected by most food handlers ${ }^{26}$.

Regarding processes and procedures (Section D), Silva $\mathrm{Jr}^{24}$ reported that during goods receiving, the first stage of hygienic and sanitary control, the receiving clerk should check the expiration date, perform sensory analysis, check the packaging, observe the conditions of the delivery person, and weigh, measure, and record the temperature of the foods that require refrigeration. In the study food services, the lack of thermometers and weighing scales prevented verification of the temperature and weight of the delivered goods.

Vegetables should be washed by immersing them in chlorine-based bleach (150 to $200 \mathrm{ppm}$ of chlorine) for 10 to 15 minutes, and both chlorinated isocyanurates and sodium hypochlorite may be used as the chlorine source ${ }^{24}$. Appropriate cleaning reduces the amount of pathogenic microorganisms to an amount compatible with our immunity ${ }^{24}$. However, most school food services did not wash the vegetables, which may place students' health at risk.

According to Kaku et al. ${ }^{27}$, poor meal preparation hygiene in a school food service located in Pontalina (SP) caused 211 people to acquire foodborne disease from a mayonnaise sauce containing raw eggs. The main symptoms were diarrhea, fever, abdominal pain, vomiting, shivering, and headache, and $38.9 \%$ of those affected required hospitalization. Analysis of biological material and leftovers attributed the disease to Salmonella enteritidis ${ }^{27}$. Although all study food services served only hard-boiled eggs, $16.4 \%$ offered preparations that contained raw eggs, which may increase the risk of foodborne disease outbreaks. 
Given that dieticians are in charge of the PNAE and that their tasks include planning, creating, following, and assessing the school food menu ${ }^{15}$, their presence in schools is critical, as well as their submitting of food handlers to periodical training to minimize risks and provide a safe and healthy menu.

Regarding table cleaning, only $52.6 \%$ of the study food services cleaned tables properly, corroborating a study done in school canteens in Andalusia (Spain) that found unsatisfactory table cleaning and disinfection conditions ${ }^{25}$.

Gomes et al. ${ }^{28}$ found that $44.4 \%$ of the 18 food services they investigated in the state of Goiás did not perform chemical pest control, different from this study, which found that only $13.8 \%$ of the food services did not perform this control.

According to RDC $n^{\circ} 216 / 2004^{29}$, food services must take measures to prevent the presence of pests and hire professional chemical pest control when their measures are not effective $^{7}$. Pest control providers must follow a series of practical and operational regulations regarding type of product used and application techniques to minimize environmental impact and ensure consumer and operator health, and service quality and safety ${ }^{29}$.

Most food handlers interviewed by the present study reported not undergoing periodical training. Frequent training minimizes the risk of foodborne diseases substantially ${ }^{30}$. Food handlers are not knowledgeable about foodborne diseases, and their work has low social status and does not require a high education level ${ }^{31}$.

The legislation determines that food handlers undergo regular training on personal hygiene, safe food handling, and foodborne diseases, and have documented proof of their participation in such training sessions ${ }^{7}$. However, many study food services did not comply with this regulation, as did not $72.2 \%$ of the 13 food services investigated by another study conducted in the state of Goiás, which did not train their food handlers ${ }^{28}$.
Since dieticians are in charge of the PNAE, they must train these professionals ${ }^{32}$. Under this perspective and given that one of the inclusion criteria was the presence of a dietician in charge of the municipal school food, it is strange that so many food handlers did not undergo training regularly or at all, which may explain the high noncompliance rates of the GHP processes and procedures.

School food services located in urban areas differed significantly from those located in rural areas. The former presented higher compliance rates for almost all study variables, except for storage lighting, ventilation, and absence of unused objects (Table 3).

The results show that, since meals are prepared at school, the school should have proper places for storing foods, and preparing and distributing meals, to minimize the risks of contamination and provide safe foods to all public school students ${ }^{23}$.

\section{CONCLUSION}

In light of the legislation, the food services of municipal schools in the Brazilian Midwest region present unsatisfactory physical and functional conditions, the food handlers do not comply with the proper hygienic and sanitary guidelines, and the GHP have not been implemented. The study results indicate that safe and quality meals cannot be guaranteed in the study schools.

The numerous noncompliances regarding the physical, plumbing, and wiring conditions of the food preparation areas and the lack of equipment suggest the need of greater interventions and involvement of municipal managers (mayor, head of the department of education), dieticians in charge of the school food, school principals, school food councils, and food handlers. Team work can ensure school compliance with food safety regulations, especially in schools located in rural areas. 
Regarding processes and procedures, food handlers must be continuously and periodically trained to minimize the risk of food contamination stemming from the poor physical conditions of the school food services.

Over the years, the PNAE has made many advances to guarantee food and nutrition security. However, all social actors who work in the program need to invest, incentivize, intervene, and work more to ensure compliance with school food-related laws (Laws $n^{\circ} 11,947 / 2009$ and $11,346 / 2006)$ and RDC n० 216/2004.

\section{A C KNOWLEDGMENTS}

We thank the public school students who motivated this study, heads of the municipal Departments of Education, school principals, food handlers, and all partners who made this study possible.

\section{CONTRIBUTORS}

KM ALMEIDA helped to conceive and design the study, collect, analyze, and interpret data, review the literature and write the article. MCP ANDRÉ helped to conceive and design the study and write and review the article. MRH CAMPOS helped to conceive and design the study and review the article. MEP DÍAZ helped to define the methodological strategy, analyze and interpret the data and write and review the article.

\section{REFERENCES}

1. Abreu ES, Spinelli MGN. A unidade de alimentação e nutrição. In: Abreu ES, Spinelli MGN, Pinto ANS. Gestão de unidades de alimentação e nutrição: um modo de fazer. $4^{\text {a }}$ ed. São Paulo: Metha; 2011. pp.35-42.

2. Brasil. Presidência da República. Lei n 11.947, de 16 de junho de 2009. Dispõe sobre o atendimento da alimentação escolar e do Programa Dinheiro Direto na Escola aos alunos da educação básica. Brasília: Presidência da República; 2009 [acesso 2012 nov 2]. Disponível em: <http://www. planalto.gov.br/ccivil_03/_ato2007-2010/2009/lei/ |11947.htm>.

3. Cardoso RCV, Góes JAW, Almeida RCC, Guimarães AG, Barreto DL, Silva SA, et al. Programa nacional de alimentação escolar: há segurança na produção de alimentos em escolas de Salvador (Bahia)? Rev Nutr. 2010; 23(5):801-11. doi: 10.1590/S1415-52 732010000500010

4. Cardoso RCV, Almeida RCC, Guimarães AG, Goes JAW, Santana AAC, Silva SA, et al. Avaliação da qualidade microbiológica de alimentos prontos para consumo servidos em escolas atendidas pelo programa nacional de alimentação escolar. Rev Inst Adolfo Lutz. 2010; 69(2):208-13.

5. Dias JC, Alvarez CR, López AS, Rodrigues AA. Estudio microbiologico de las comidas servidas en los comedores escolares de la isla de Tenerife. Rev Española Salud Pública. 2003; 21(7):623-8. doi: 10.1590/S1135-57272010000300001

6. Brasil. Ministério da Saúde. Portal da Saúde. Doenças transmitidas por alimentos. Brasília: Ministério da Saúde; 2013 [acesso 2013 mar 22]. Disponível em: <http://portal.saude.gov.br/portal/saude/ profissional/area.cfm?id_area=1550>.

7. Agência Nacional de Vigilância Sanitária. Resolução RDC $n^{\circ} 216$, de 15 de setembro de 2004. Dispõe sobre regulamento técnico de boas práticas para serviços de alimentação. Brasília: Anvisa; 2004 [acesso 2012 nov 2]. Disponível em: <http://www. anvisa.gov.br/legis/resol/2004/rdc/216_04rdc. htm>.

8. Marchezetti MA. Aspectos físicos do serviço de alimentação. In: Silva Jr EA. Manual de controle higiênico-sanitário em serviço de alimentação. $6^{\mathrm{a}}$ ed. São Paulo: Livraria Varela; 2005.

9. Oliveira MN, Brasil ALD, Taddei, JAAC. Avaliação das condições higiênico-sanitárias das cozinhas de creches públicas e filantrópicas. Ciênc Saúde Colet. 2008; 13(3):1051-60. doi: 10.1590/\$1413-8123 2008000300028

10. Rosa MS, Negreiros SRF, Seabra LMAJ, Stamford TLM. Monitoramento de tempo e temperatura de distribuição de preparações à base de carne em escolas municipais de Natal (RN), Brasil. Rev Nutr. 2008; 21(1):21-8. doi: 10.1590/S1415-52732008 000100003

11. Santana NG, Almeida RGC, Ferreira JS, Almeida PF. Microbiological quality and safety of meals served to children and adoption of good manufacturing practices in public school catering in Brazil. Food Control. 2009; 20(3):255-61. doi: 10.1016/j.food cont.2008.05.004

12. Silva C, Germano MIS, Germano PML. Condições higiênico-sanitárias dos locais de preparação da merenda escolar, da rede estadual de ensino em São Paulo, SP. Hig Aliment. 2003; 17(110):49-55.

13. Brasil. Presidência da República. Lei $n^{\circ} 11.346$, de 15 de setembro de 2006. Cria o Sistema Nacional de Segurança Alimentar e Nutricional - SISAN com vistas em assegurar o direito humano à alimentação adequada e dá outras providências. Brasília: Presi- 
dência da República; 2006 [acesso 2014 jan 7]. Disponível em: <http://www.planalto.gov.br/ccivil_ 03/_ato2004-2006/2006/lei/111346.htm>.

14. Brasil. Ministério do Desenvolvimento Social e Combate à Fome. Estruturando o Sistema Nacional de Segurança Alimentar e Nutricional - SISAN. Brasília: Ministério do Desenvolvimento Social e Combate à Fome; 2011.

15. Brasil. Ministério da Educação. Resolução/FNDE/CD/ $n^{\circ} 26$, de 17 de julho de 2013. Dispõe sobre o atendimento da alimentação escolar aos alunos da educação básica no Programa Nacional de Alimentação Escolar - PNAE. Brasília: Ministério da Educação; 2013 [acesso 2013 jul 12]. Disponível em: <http://www.fnde.gov.br/fnde/legislacao/ resolucoes/item/4620-resolu \% C3\%A7\% C3\% A3o-cd-fnde-n\%C2\%BA-26,-de-17-de-junho-de2013>.

16. Medronho RA, Bloch KV, Luiz RR, Werneck GL. Epidemiologia. $2^{a}$ ed. São Paulo: Atheneu; 2009.

17. Centro Colaborador em Alimentação e Nutrição do Escolar da Universidade Federal de Goiás e Região Centro-Oeste. Relatório parcial: apoio técnico, consultoria e acompanhamento da execução do PNAE nos municípios. Goiânia: Cecane; 2012.

18. Hoffmann R. Estatística para economistas. São Paulo: Thonson Learning; 2006.

19. Centro Colaborador em Alimentação e Nutrição do Escolar. Sistema de monitoramento do programa nacional de alimentação escolar: manual do usuário. Santos: Universidade Federal de São Paulo; 2010.

20. Centers for Disease Control and Prevention. Estimating foodborne illness: An overview. Atlanta (GA): Centers for Disease Control and Prevention; 2013 [cited 2013 Jul 15]. Available from: <http:// www.cdc.gov/foodborneburden/estimatesoverview.html>.

21. Brasil. Ministério da Saúde. Situação epidemiológica. Dados epidemiológicos: DTA período de 2000 a 2011. Brasília: Ministério da Saúde [acesso 2013 mar 20]. Disponível em: <http://portal.saude.gov.br/ portal/arquivos/pdf/dados_dta_periodo_2000_ 2011_site.pdf>.

22. Ebone MV, Cavalli SB, Lopes SJ. Segurança e qualidade higiênico-sanitária em unidades produtoras de refeições comerciais. Rev Nutr. 2011; 24(5):725-34. doi: 10.1590/S1415-52732012000400005

23. Uduku O. School building design for feeding programmes and community outreach: Insights from Ghana and South Africa. Int J Educ Dev. 2011; 31(1):59-66. doi: 10.1016/j.ijedudev.2010.06.005

24. Silva Jr. EA. Manual de controle higiênico-sanitário em serviço de alimentação. $6^{a}$ ed. São Paulo: Livraria Varela; 2005.

25. Rodríguez-Caturla MY, Valero A, Carrasco E, Posada GD, García-Gimeno R, Zurera G. Evaluation of hygiene practices and microbiological status of ready-to-eat vegetable salads in Spanish school canteens. J Sci Food Agric. 2012; 92(11):2332-40. doi: 10.1002/jsfa.5634

26. Tan SL, Bakar FA, Karim MSA, Lee HY. Hand hygiene knowledge, attitudes and practices among food handlers at primary schools in Hulu Langat district, Selangor (Malaysia). Food Control. 2013; 34(2):428-35. doi: 10.1016/j.foodcont.2013.0 4.045

27. Kaku M, Peresi JTM, Tavechio AT, Fernandes SA, Batista $A B$, Castanheira IAZ, et al. Surto alimentar por Salmonella Enteritidis no noroeste do Estado de São Paulo, Brasil. Rev Saúde Pública. 1995; 29(2):290-94. doi: 10.1590/S0034-8910199500 0200007

28. Gomes NAA, Campos MRH, Monego ET. Aspectos higiênico-sanitários no processo produtivo dos alimentos em escolas públicas do estado de Goiás, Brasil. Rev Nutr. 2012; 25(4):473-85. doi: 10.1590/ S1415-52732012000400005

29. Agência Nacional de Vigilância Sanitária. Resolução RDC $n^{\circ} 52$, de 22 de outubro de 2009. Dispõe sobre o funcionamento de empresas especializadas na prestação de serviço de controle de vetores e pragas urbanas e dá outras providências. Brasília: Ministério da Saúde; 2009 [acesso 2014 jan 12]. Disponível em: <http://portal.anvisa.gov.br/wps/ wcm/connect/3ce8080047fe 1 a8abc40be9f30 6e0947/RDC+52.2009.pdf?MOD=AJPERES>.

30. Abdul-Mutalib NA, Abdul-Rashid MF, Mustafa S, Amin-Nordin S, Hamat RA, Osman M. Knowledge, attitude and practices regarding food hygiene and sanitation of food handlers in Kuala Pilah, Malaysia. Food Control. 2012; 27(2):289-93. doi: 10.1016/ j.foodcont.2012.04.001

31. Colombo M, Oliveira KMP, Silva DLD. Conhecimento das merendeiras de Santa Fé, PR sobre higiene e boas práticas de fabricação na produção de alimentos. Hig Aliment. 2009; 23(170/171):39-46.

32. Conselho Federal de Nutricionistas. Resolução CFN $n^{\circ} 465 / 2010$. Dispõe sobre as atribuições do Nutricionista, estabelece padrões numéricos mínimo de referência no âmbito do Programa de Alimentação Escolar (PAE) e dá outras providências. Brasília: Conselho Federal de Nutricionistas; 2010 [acesso 2012 nov 30]. Disponível em: <http://www.cfn.org.br/ novosite/arquivos/Resol-CFN-465-atribuicaonutricionista-PAE.pdf>.

Received on: 8/8/2013

Final version on: $1 / 16 / 2014$ Approved on: 2/26/2014 